С.Й. Шаманський, канд. техн. наук, М.С. Бойченко, аспірант;

Л.І. Павлюх, канд. техн. наук, доц., Національний авіаційний університет

\title{
МОДЕЛЮВАННЯ МАСОВОЇ ТА ЛІПІДНОЇ ПРОДУКТИВНОСТІ КУЛЬТИВУВАННЯ МІКРОВОДОРОСТЕЙ В УМОВАХ КИЇВСЬКОЇ ОБЛАСТІ
}

\begin{abstract}
У статті проаналізовано перспективи виробництва біопалива третього та четвертого поколінь. Запропоновано культивування мікроводоростей з високим вмістом ліпідів у біомасі як сировини для изього виробництва. Розглянуто вплив інтенсивності освітлення культурального середовища на продуктивність культивування, використовуючи енергетичний баланс фотосинтезу. Запропоновано математичну модель розрахунку продуктивності культивування у відкритих ємностях залежно від інтенсивності сонячного опромінення. На основі середньомісячних рівнів сонячної радіацї у місті Києві, отриманими $N A S A$, що є усередненими на підставі 20-річних спостережень за рівнем освітленості території Украӥни, оцінено продуктивність культивування протягом року для погодних умов Київької області, використовуючи запропоновану модель. Отриману продуктивність порівняно з продуктивністю, що може бути досягнута у інших частинах світу. Для підвищення економічної ефективності виробництва біопалива запропоновано використання як культурального середовища попередньо очищених традиційними методами комунальних стічних вод. Це дасть змогу поєднати процеси вирощування сировини для біопалива і прочеси очищення стічних вод від біогенних елементів.
\end{abstract}

Ключові слова: біопаливо, продуктивність культивування, ліпіди, очищення стічних вод, біогенні елементи.

Постановка проблеми. Роль біопалива як джерела енергії у суспільстві зростає 3 кожним днем. Розрізняють біопаливо чотирьох поколінь [1-17]. Для виробництва біопалива першого покоління як сировину використовують традиційні сільськогосподарські культури, що одночасно є сировиною для виробництва продуктів харчування. Невідворотність продовольчої кризи у майбутньому робить необхідним пошуки іншої сировини для виробництва енергоносіїв. Паливо другого покоління виробляють з сировини, що не може бути використана для харчового виробництва. Це відходи сільського господарства, відходи деревообробки, відходи харчової промисловості, а також технічні культури, що спеціально для цього вирощуються. Складнощі з переробленням відходів та невеликий вихід готового продукту, а також необхідність відведення родючих земельних площ під технічні культури також робить актуальним пошуки іншої сировини. Біопаливо третього та четвертого поколінь перспективно виробляти з біомаси водоростей. Багато з них можуть більш ефективно конвертувати сонячну енергію у біомасу ніж грунтові культури, зв’язуючи при цьому вуглекислий газ із атмосфери [13].

Серед водних культур найбільш цікавими можна вважати мікроводорості. Порівняно 3 макроводоростями, цінність перших полягає перш за все у тому, що вони мають просту будову, є невибагливими, швидко ростуть та мають високий вміст олій. Біомаса різних штамів містить різну кількість білків вуглеводів та ліпідів. Проте, не дивлячись на їх значний вміст у біомасі багатьох штамів і потенційну можливість використання для різних потреб, на теперішній час дуже мало штамів знайшли комерційне застосування. Серед тих, що найбільш широко використовуються у світі можна назвати такі: Chlorella vulgaris, Dunaliella saliina, Spirulina, Наematococcus pluvialis [14].

Аналіз останніх досліджень і публікацій. Мікроводорості відрізняються також тим, що можуть рости у дуже різноманітних середовищах. Для них підходить як прісна вода, так і надзвичайно солона [15]. Багато зі штамів цих організмів можуть добре пристосовуватися до нових умов, що полегшує створення технологій їх культивування. Крім того деякі штами містять значні відсотки ліпідів у сухій біомасі, що робить їх привабливими як сировину для біопалива. Зустрічаються штами зі вмістом ліпідів більше $70 \%$, а деякі, за певних умов культивування, можуть містити навіть більше 80 \% [1]. Біохімічні методи четвертого покоління (біопаливо четвертого покоління) значною мірою пов'язані з обміном речовин під випливом мікроорганізмів, щоб виділяти біобутанол, біоетанол тощо [13]. Четверте покоління біопаливфотобіологічних сонячних палив та електропалив, як очікується, є найбільш прогресивним і принесе фундаментальні прориви в галузі біопалива. Технологія виробництва такого сонячного біопалива є новою галуззю, заснованою на прямому перетворенні сонячної енергії в паливо з використанням невичерпної, дешевої та широко доступної сировини через культивацію біомаси.

(С) С. Й. Шаманський, М.С Бойченко., Л.І. Павлюх, 2017 
Світовий досвід свідчить [14], що біодизель, вироблений з біомаси мікроводоростей, має подібні експлуатаційні властивості до традиційного біодизелю.

Проте культивування мікроводоростей вимагає також певних умов навколишнього середовища, а саме не надто низьких температур та наявності достатньої кількості сонячного світла для забезпечення процесу фотосинтезу. Ці умови можна вважати обмежуючими факторами щодо продуктивності процесу культивування.

Мета статті - розробити математичну модель розрахунку продуктивності культивування мікроводоростей у відкритих ємностях залежно від інтенсивності освітлення та оцінено продуктивність такого культивування протягом року для погодних умов Київської області.

Викладення основного матеріалу. Під час вирощування мікроводоростей у відкритих ємностях, вони піддаються впливам різних погодних умов, перш за все змінам температури та інтенсивності сонячного освітлення, пов'язаних з частинами доби та зміною сезонів. Ці впливи позначаються на продуктивності культивування, у результаті чого змінюється кількість біомаси та кількість ліпідів отриманих з одиниці площі, відведеної для культивування.

Середня інтенсивність сонячної радіації, що досягає поверхні земної атмосфери (сонячна стала), за даними Всесвітньої метеорологічної організації, складає $1367 \mathrm{BT} / \mathrm{M}^{2}$ (густина потоку фотонів 2555,5 мкмоль $/ \mathrm{M}^{2} \cdot$ сек). Через відбивання та розсіювання атмосферою поверхні землі досягає максимум $1000 \mathrm{BT} / \mathrm{M}^{2}$ (2162 мкмоль $/ \mathrm{M}^{2}$-сек). Реальна інтенсивність сонячної радіації, що досягає земної поверхні може коливатися у широких межах, а саме від $50 \mathrm{BT} / \mathrm{M}^{2}\left(108,1\right.$ мкмоль/ ${ }^{2} \cdot$ сек) при затягнутому хмарами небі до $1000 \mathrm{BT} / \mathrm{M}^{2}\left(2162\right.$ мкмоль $/ \mathrm{M}^{2} \cdot$ сек) При цьому середня інтенсивність у більшості районів земної кулі коливається від 200 (432,4 мкмоль $/ \mathrm{M}^{2}$.сек) до $250 \mathrm{BT} / \mathrm{M}^{2}\left(540,5\right.$ мкмоль $/ \mathrm{M}^{2} \cdot$ сек).

Залежно від регіону максимальна кількість енергії, що надходить на земну поверхню в Україні за день, може досягати $330 \mathrm{Bт} / \mathrm{m}^{2}\left(713,5\right.$ мкмоль $/ \mathrm{M}^{2} \cdot$ сек) влітку і $125 \mathrm{Bт} / \mathrm{m}^{2}\left(270,3\right.$ мкмоль $/ \mathrm{M}^{2} \cdot$ сек) взимку (у безхмарні сонячні дні).

Не вся енергія сонячного випромінювання може використовуватися для процесів фотосинтезу. 3 усього спектру випромінювання сонця використовується діапазон фотосинтетично активного випромінювання (ФАВ) від 400 до 700 нм довжини хвилі, що майже співпадає з видимим світлом (380780 нм). Інтенсивність фотосинтезу у цьому діапазоні не $\epsilon$ величиною сталою. Залежність інтенсивності фотосинтезу від довжини хвилі показано на рис. 1.

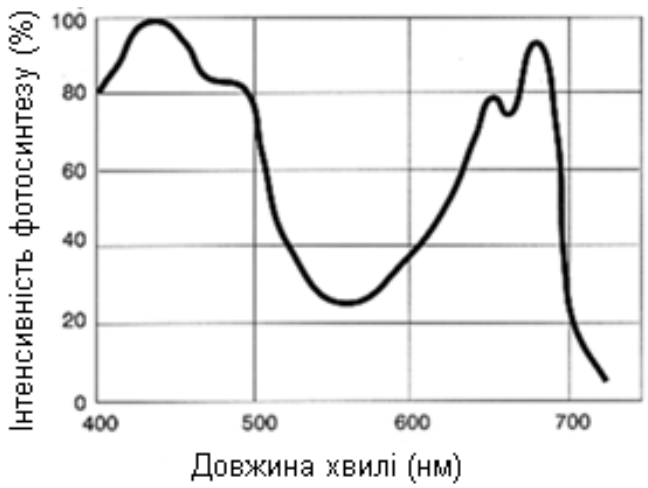

Рисунок 1 - Залежність інтенсивності фотосинтезу від довжини хвилі у діапазоні ФАВ [18]

На цей діапазон припадає близько 47 \% енергії сонячного випромінювання.

Відомо, що під час фотосинтезу для поглинання однієї молекули $\mathrm{CO}_{2} 3$ перетворенням ії у вуглеводи (емпірична формула $\mathrm{C}_{\mathrm{m}}\left(\mathrm{H}_{2} \mathrm{O}\right)_{\mathrm{n}}$ використовується 8 фотонів [14]. Середню енергію одного фотона в діапазоні ФАВ оцінюють у 217,4 кДж. Теплоту згоряння одного моля $\mathrm{C}\left(\mathrm{H}_{2} \mathrm{O}\right)$, а отже запасену у ньому енергію, оцінюють у 468 кДж/моль. Виходячи 3 цього, максимальна теоретична ефективність перетворення енергії ФАВ у вуглеводні визначиться за формулою:

Ця ефективність складе:

$$
\varepsilon_{\Phi \mathrm{AB} \rightarrow \mathrm{C}_{m}\left(\mathrm{H}_{2} \mathrm{O}\right)_{n}}=\frac{\varepsilon_{\mathrm{C}_{m}\left(\mathrm{H}_{2} \mathrm{O}\right)_{n}}}{8 \times \varepsilon_{\Phi \mathrm{AB}}} \times 100 \%
$$

$$
\varepsilon_{\Phi \mathrm{AB} \rightarrow \mathrm{C}_{m}\left(\mathrm{H}_{2} \mathrm{O}\right)_{n}}=\frac{468}{8 \times 217,4} \times 100 \%=26,9 \%
$$

Крім того, під час передачі сонячної енергії організмам мікроводоростей відбуваються також додаткові її втрати через розсіювання та відбивання. Ці втрати оцінюють у додаткові 10 \% [17]. Тобто ефективність засвоєння з урахуванням розсіювання та відбивання складає:

$$
\varepsilon_{\text {розс.відбив }}=100 \%-10 \%=90 \%
$$




\section{ISSN 1813-5420 (Print). Енергетика: економіка, технології, екологія. 2017. № 4}

Таким чином максимальна теоретична ефективність засвоєння усієї сонячної енергії у процесі фотосинтезу може бути оцінена

$$
\varepsilon_{\text {засв.сон.ен }}=0,47 \times 0,269 \times 0,9 \times 100 \%=11,38 \%
$$

Така модель недостатньо добре відображає реальність, оскільки за даними [17], ефективність засвоєння сонячної енергії в реальних (польових) умовах мікроводоростями під час культивування їх у відкритих ємностях переважно коливається в інтервалі 3-6\%. Таке зниження ефективності досягається додатковими втратами енергії на нічне дихання, фотоінгібування тощо.

Розглянемо вплив інтенсивності освітлення культурального середовища на продуктивність культивування, використовуючи енергетичний баланс фотосинтезу [19]. Добову продуктивність за біомасою одиниці площі водойми $\Pi_{б і о м}$ можна визначити за формулою:

$$
\Pi_{\text {біом }}=\frac{I_{\text {опром }}}{E_{\text {біом }}} \times k_{\text {пер }} \times k_{\text {конв }},\left(\frac{\Gamma}{\mathrm{M}^{2} \cdot \text { добу }}\right)
$$

де $I_{\text {опром }}$ - енергія сонячної радіації, що падає на одиницю площі у місці розташування водойми 3 культуральною рідиною та мікроводоростями (кДж/м².добу); $E_{\text {біом }}$ - кількість енергії, що запасається в одиниці маси мікроводоростей, що культивуються (МДж/кг); $k_{\text {пер }}$ - коефіцієнт, що враховує ефективність передавання енергії сонячного випромінювання особинам мікроводоростей; $k_{\text {конв }}-$ коефіцієнт, що враховує ефективність конверсії енергії отриманого сонячного випромінювання особинами мікроводоростей у біомасу.

Коефіцієнт ефективності передавання енергії може бути визначений за формулою:

$$
k_{\text {пер }}=k_{\text {розп }} \times k_{\text {площ }} \times k_{\text {фотосинт }} \times k_{\text {абс }} \text {, }
$$

де $k_{\text {розп }}$ - коефіцієнт, що враховує ефективність розповсюдження сонячного світла через культуральне середовище (розсіювання на шляху); $k_{\text {площ }}-$ коефіцієнт, що враховує ефективність використання площі падіння сонячного випромінювання (відношення робочої поверхні культуральної рідини до усієї поверхні опромінення); $k_{\text {фотосинт }}-$ коефіцієнт, що враховує частину сонячного випромінювання, що припадає на спектр, активний при фотосинтезі; $\quad k_{\text {абс }}-$ коефіцієнт абсорбції світла мікроводоростями.

Коефіцієнт конверсії енергії отриманого сонячного випромінювання у біомасу може бути визначений за формулою:

$$
k_{\text {конв }}=k_{\text {погл.фотон }} \times k_{\text {засв.фотон }} \times\left(1-k_{\text {дих }}\right) \text {, }
$$

де $k_{\text {погл.фотон }}$ - коефіцієнт, що враховує ефективність поглинання фотонів випромінювання у процесі фотосинтезу; $k_{\text {засв.фотон }}$ - коефіцієнт, що враховує ефективність засвоєння енергії фотонів у процесі фотосинтезу; $k_{\text {дих }}-$ коефіцієнт врахування частини енергії, що витрачається у темний період доби для забезпечення процесу нічного дихання.

Теоретично, за оптимальних умов, клітини мікроводоростей можуть засвоювати практично усі

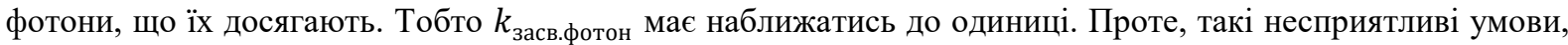
як високий рівень освітленості, відхилення від оптимальної температури, за яких посилюються ефекти фотоінгібіювання, знижують значення цього коефіцієнта. За підвищеної температури поглинуті фотони,

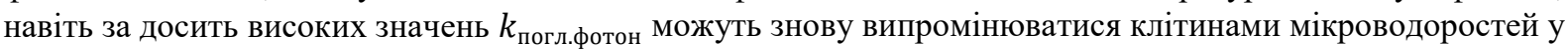
навколишне середовище як теплове випромінювання. За занадто інтенсивного освітлення поглинуті фотони можуть здійснювати руйнівний вплив на клітини.

Можна стверджувати, що рівень ефективності засвоєння фотонів залежить від рівня освітленості, температури середовища та інших умов. Особливо значний вплив на цей показник здійснює рівень освітлювання.

Процес фотосинтезу характеризується поняттям насичення. 3 огляду на рівень освітлення насиченням називають такий його рівень, при котрому інтенсивність фотосинтезу досягає найбільшого значення.

Залежність інтенсивності фотосинтезу від інтенсивності освітлення в цілому є логарифмічною. Пряма залежність спостерігається лише при низьких інтенсивностях освітлення. При збільшення освітленості фотосинтез посилюється.

Проте, при збільшенні інтенсивності освітлення понад інтенсивність насичення для багатьох штамів мікроводоростей інтенсивність фотосинтезу зменшується.

У більшості випадків світлове насичення досягається при густині потоку фотонів 200 мкмоль $/ \mathrm{m}^{2} \cdot$ сек $\left(92,5 \mathrm{BT} / \mathrm{M}^{2}\right)[20]$.

Коефіцієнт ефективності засвоєння енергії фотонів можна визначити за формулою:

$$
k_{\text {засв.фот }}=\frac{I_{\text {насич }}}{I_{\text {пад }}} \times\left[\ln \left(\frac{I_{\text {пад }}}{I_{\text {насич }}}\right)+1\right] \text {, }
$$

де $I_{\text {насич }}$ - густина насичення фотосинтетично активної радіації опромінюваного світла (мкмоль $/ \mathrm{M}^{2} \cdot$ сек); $I_{\text {пад }}$ - густина фотосинтетично активної радіації падаючого світла (мкмоль $/ \mathrm{M}^{2} \cdot$ сек). 


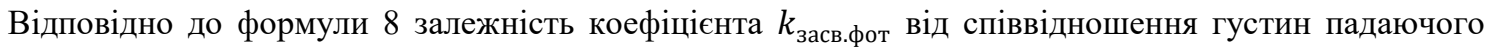
випромінювання та випромінювання насичення $\frac{I_{\text {пад }}}{I_{\text {насич }}}$ має логарифмічний характер. Графічно цю залежність наведено на рисунку 2.

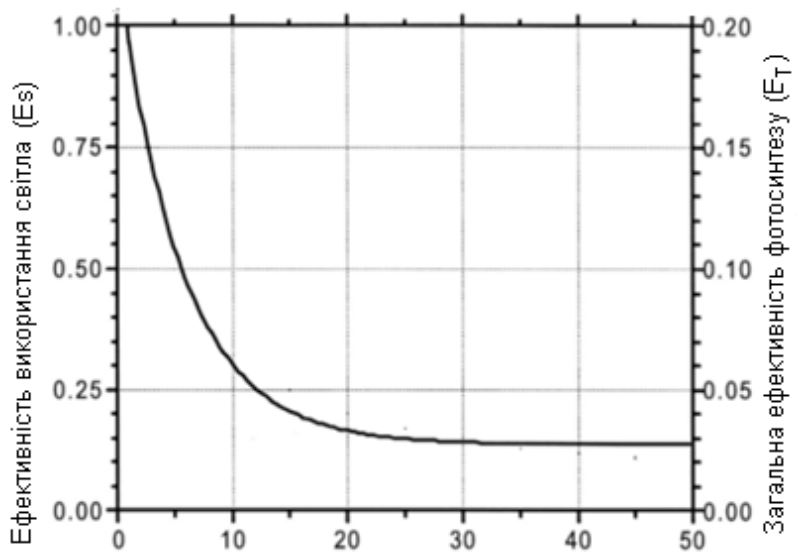

Рисунок 2 - Залежність коефіцієнта ефективності засвоєння енергії фотонів від співвідношення густин падаючого випромінювання та випромінювання насичення

Така залежність справедлива тільки для умови, коли $\frac{I_{\text {пад }}}{I_{\text {насич }}} \geq 1$. Тобто коли густина падаючого випромінювання не менше густини насичення. При цьому з наближенням $\frac{I_{\text {пад }}}{I_{\text {насич }}}$ до одиниці, $k_{\text {засв.фот }}$ зростає до одиниці. У діапазоні коли $\frac{I_{\text {пад }}}{I_{\text {насич }}}<1$, зі зменшенням значення цього співвідношення значення $k_{\text {засв.фот }}$ стрімко зменшується, що не відповідає експериментальним даним, відповідно до яких, при малих значеннях густини опромінення цей коефіцієнт залишається близьким до одиниці. Тому формулу 8 доцільно використовувати тільки за умови $\frac{I_{\text {пад }}}{I_{\text {насич }}} \geq 1$.

Добову продуктивність по синтезу ліпідів одиниці площі водойми П формулою:

$$
\Pi_{\text {ліп }}=\frac{k_{\text {ліп }} \times \Pi_{\text {бімм }}}{\rho_{\text {ліп }}},\left(\frac{\text { мл }}{\mathrm{m}^{2} \text { добу }}\right),
$$

де $k_{\text {ліп }}$ - коефіцієнт, що враховує вміст ліпідів у біомасі мікроводоростей, що можуть бути використані для виробництва готової продукції (наприклад біопалива); $\rho_{\text {ліп }}-$ густина ліпідів (кг/л).

Розрахуємо продуктивність протягом року за біомасою та продуктивністю за ліпідами під час культивування мікроводоростей у відкритих ємкостях за умов здійснення процесу у Київській області.

За даними NASA, що є усередненими на підставі 20 річних спостережень за рівнем освітленості території України, середньомісячний рівень сонячної радіації у місті Києві наведено у таблиці 1.

Таблиця 1 - Середній місячний рівень сонячної радіації у місті Києві [21]

\begin{tabular}{|c|c|c|c|c|c|c|c|c|c|c|c|c|}
\hline Місяць & 01 & 02 & 03 & 04 & 05 & 06 & 07 & 08 & 09 & 10 & 11 & 12 \\
\hline $\begin{array}{c}I_{\text {опром' }} \\
\frac{\text { кВтггод }}{\mathrm{M}^{2} \text { добу }}\end{array}$ & 1,07 & 1,87 & 2,95 & 3,96 & 5,25 & 5,22 & 5,25 & 4,67 & 3,12 & 1,94 & 1,02 & 0,86 \\
\hline
\end{tabular}

Розраховуємо продуктивність при культивуванні у липні місяці.

Продуктивність мікроводоростей за біомасою визначаємо за формулою 5. Для цього переводимо

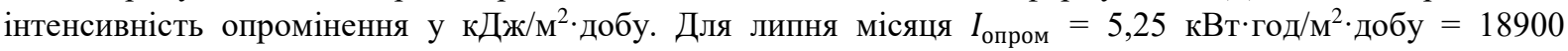

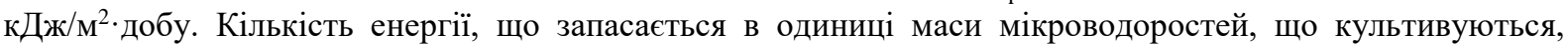
прийнято $E_{\text {біом }}=14,21 \mathrm{MДж/кг} \mathrm{[14].}$

Коефіцієнт, що враховує ефективність передавання енергії сонячного випромінювання особинам мікроводоростей, визначаємо за формулою 6: 


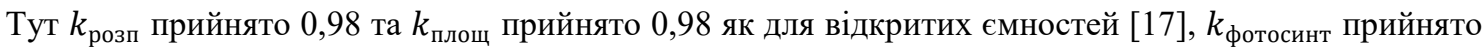
0,458 [22], $k_{\text {абс }}$ - прийнято 1,0 [19].

Коефіцієнт конверсії енергії отриманого сонячного випромінювання у біомасу визначаємо за формулою 7. Для цього попередньо визначаємо коефіцієнт ефективності засвоєння енергії фотонів за формулою 8:

$$
k_{\text {засв.фот }}=\frac{200}{460,9} \times\left[\ln \left(\frac{460,9}{200}\right)+1\right]=0,79
$$

Тут $I_{\text {насич }}$ прийнято 200 (мкмоль $/ \mathrm{M}^{2} \cdot$ сек) [20], $I_{\text {пад }}$ виражено у відповідних одиницях $I_{\text {пад }}=5,25$

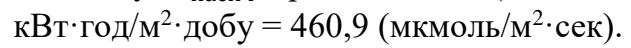

Таким чином коефіцієнт конверсії складе:

$$
k_{\text {конв }}=0,269 \times 0,79 \times(1-0,2)=0,170
$$

Тут $k_{\text {погл.фотон }}=0,269$ (див. розрахунок ефективності перетворення енергії ФАВ у вуглеводні $\varepsilon_{\Phi А В \rightarrow C_{m}\left(H_{2} O\right)_{n}}$, що виконано вище), $k_{\text {дих }}$ прийнято 0,2 [19].

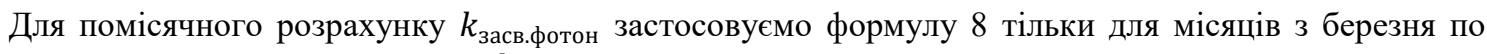
вересень, коли задовольняється умова $\frac{I_{\text {пад }}}{I_{\text {насич }}} \geq 1$. Для решти місяці приймаємо $k_{\text {засв.фотон }}=0,99$.

Продуктивність мікроводоростей за біомасою, визначена за формулою 5, складе

$$
\Pi_{\text {біом }}=\frac{18900}{14,21} \times 0,44 \times 0,170=99,5,\left(\frac{\Gamma}{\text { м² добу }^{2}}\right)
$$

Продуктивність за синтезом ліпідів визначаємо за формулою 9.

$$
\Pi_{\text {ліп }}=\frac{0,2 \times 99,5}{0,85}=23,41,\left(\frac{\text { мл }}{\text { м².добу }^{2}}\right)
$$

Тут коефіцієнт вмісту ліпідів у біомасі, що можуть бути використані $k_{\text {ліп }}$, прийнято 0,2 , що $є$ одним 3 найнижчих, враховуючи дані джерел $[23,24,25,26]$, густину виділеної з біомаси олії (ліпідів) $\rho_{\text {ліп }}$ прийнято 0,85 кг/л [27].

\begin{tabular}{|c|c|c|c|c|c|c|c|c|c|c|c|c|}
\hline Місяць & 01 & 02 & 03 & 04 & 05 & 06 & 07 & 08 & 09 & 10 & 11 & 12 \\
\hline $\begin{array}{l}I_{\text {опром }} \\
\frac{\text { кВт·год }}{\mathrm{M}^{2} \cdot \text { добу }}\end{array}$ & 1,07 & 1,87 & 2,95 & 3,96 & 5,25 & 5,22 & 5,25 & 4,67 & 3,12 & 1,94 & 1,02 & 0,86 \\
\hline $\begin{array}{l}I_{\text {опром }} \\
\frac{\text { кДж }}{\mathrm{M}^{2} \cdot \text { добу }}\end{array}$ & 3852 & 6732 & 10620 & 14256 & 18900 & 18792 & 18900 & 16812 & 11232 & 6984 & 3672 & 3096 \\
\hline $\begin{array}{l}I_{\text {опром }} \\
\frac{\text { мкмоль }}{\mathrm{m}^{2} \cdot \text { сек }}\end{array}$ & 205,1 & 358,4 & 565,4 & 759,0 & 1006,3 & 1000,5 & 1006,3 & 895,1 & 598,0 & 371,8 & 195,5 & 164,8 \\
\hline
\end{tabular}

Результати розрахунку для решти місяців року зводимо до таблиці 2.

Таблиця 2 - Розрахунок помісячної продуктивності культивування мікроводоростей в умовах міста Києва 
ISSN 1813-5420 (Print). Енергетика: економіка, технології, екологія. 2017. № 4

\begin{tabular}{|c|c|c|c|c|c|c|c|c|c|c|c|c|}
\hline \hline $\begin{array}{c}I_{\text {ФАА }} \\
\frac{\text { мкмоль }}{\text {.сек }^{2}}\end{array}$ & 93,9 & 164,1 & 258,9 & 347,6 & 460,9 & 458,2 & 460,9 & 409,9 & 273,9 & 170,3 & 89,5 & 75,5 \\
\hline$k_{\text {засв.фотон }}$ & 0,99 & 0,99 & 0,97 & 0,90 & 0,79 & 0,80 & 0,79 & 0,84 & 0,96 & 0,99 & 0,99 & 0,99 \\
\hline$k_{\text {конв }}$ & 0,213 & 0,213 & 0,209 & 0,194 & 0,170 & 0,172 & 0,170 & 0,181 & 0,207 & 0,213 & 0,213 & 0,213 \\
\hline$\Pi_{\text {біом }}$ & 25,4 & 44,4 & 68,7 & 85,6 & 99,5 & 100,1 & 99,5 & 94,2 & 72,0 & 41,1 & 24,2 & 20,4 \\
\hline$\Pi_{\text {ліп }}$ & 5,98 & 10,45 & 16,16 & 20,14 & 23,41 & 23,55 & 23,41 & 22,16 & 16,90 & 10,84 & 5,69 & 4,80 \\
\hline
\end{tabular}

Виходячи 3 отриманих результатів, під час культивування мікроводоростей в умовах Києва річна продуктивність по біомасі складе 22,86 кг/м2, річна продуктивність по ліпідах складе 5,35 кг/м2.

Культивування мікроводоростей у промислових масштабах стикається з багатьма труднощами, перш за все економічного характеру. Забезпечення достатньої кількості культурального середовища вимагає використання значних об’ємів води та поживних речовин. Значними також $є$ затрати на електроенегію для перемішування культурального середовища 3 мікроводоростями з метою забезпечення рівномірного освітлення. Під час культивування у холодний період року необхідно підігрівання для температурної стабілізації. Культивування в умовах України також поступається багатьом регіонам світу за кількістю сонячної енергії, що досягає земної поверхні. Так, середньорічна кількість енергії сонячної радіації для міста Києва складає 3,1 кВт·год/м2, для міста Дніпро - 3,36 кВт·год/м2, для міста Херсон 3,55 кВт·год/м2, для міста Львів - 2,92 кВт·год/м2. Разом з тим, цей показник для США (штат Техас) складає 4,7 кВт·год/м2, для Іспанії (Мадрид) - 4,75 кВт·год/м2, для Індії (Ченнаї) - 5,23 кВт·год/м2, для Автралії (Квінсленд) - 5,90 кВт·год/м2, для Ефіопії - 6,14 кВт·год/м2 [14].

Разом з тим мікроводорості мають властивості у процесі фотосинтезу поглинати з культурального середовища біогенні елементи, перш за усе сполуки азоту та фосфору [28, 29, 30].

Враховуючи це, для підвищення економічної ефективності процесів культивування їх доцільно поєднати з процесами очищення комунальних стічних вод від біогенних елементів. При цьому стічні води мають попередньо пройти механічне та біологічне очищення традиційними методами для набуття достатнього рівня прозорості [31]. Такі стічні води містять значну кількість біогенних елементів (сполук азоту та фосфору), а також інших поживних речовин. Їх концентрація на виході з традиційних очисних споруд не $\epsilon$ постійною, а коливається залежно від багатьох факторів. Скидання цих елементів у відкриті водойми разом зі стічними водами часто є причиною евтрофікації цих водойм (швидкого розвитку фітопланктону у воді, перш за все на ії поверхні). Це знижує здатність світла та кисню проникати у товщу води, а їх нестача там призводить до загибелі флори та фауни. Мікроводорості є гарними поглиначами біогенних елементів. Вони використовують азотні та фосфорні сполуки у процесі фотосинтезу. Їх видалення зі стічних вод знижує ризики розвитку евтрофікаційних процесів у водоймах.

Висновки.

Мікроводорості можна вважати перспективною сировиною для виробництва біопалива третього та четвертого поколінь. Під час їх культивування у відкритих водоймах за природних умов Київської області можна досягати продуктивності 22,86 кг/м2 за рік. При цьому продуктивність за ліпідами може складати 5,35 кг/м2 за рік. Враховуючи затрати на забезпечення процесу культивування, перш за усе на приготування культурального розчину, температурну стабілізацію та електричну енергію на перемішування, економічна ефективність цього процесу може бути невисокою. Для підвищення цієї ефективності доцільним може бути поєднання процесів культивування 3 процесами очищення комунальних стічних вод від біогенних елементів. Тим самим можна знижувати ризики розвитку евтрофікаційних процесів у відкритих водоймах під час скидання до них очищених стічних вод.

\section{Список використаної літератури}

1. Сорокина К. Н., Яковлев В. А., Пилигаев А. В., Кукушкин Р. Г., Пельтек С. Е., Колчанов Н. А., Пармон В. Н. Потенциал применения микроводорослей в качестве сырья для биоэнергетики // Катализ в промышленности. - 2012. №2. - С. 63-72.

2. Бойченко С. В. Раціональне використання вуглеводневих палив. - К.: НАУ, 2001. -216 с.

3. Вступ до хіммотології палив та олив: Навчальний посібник у двох частинах / Бойченко С. В., Спіркін В. Г. - Одеса: «Астропринт», 2009. - Ч. 1. - 236 с.

4. Aksenov A. F., Seregin E. P., Yanovskii L. S., and Boichenko S. V. Modern Paradigm and Prospects of Chemmotology Development // Chemistry and Technology of Fuels and Oils. - № 4 (578). - 2013. - P. 13-20.

5. Бойченко Сергій. Хіммотологія як прикладна наука - інтегрований теоретико-методологічний інструмент сталого забезпечення раціонального використання паливно-мастильних матеріалів / Олександр 


\section{ISSN 1813-5420 (Print). Енергетика: економіка, технології, екологія. 2017. № 4}

Аксьонов, Сергій Бойченко, Казимир Лейда // Проблеми хіммотології. Теорія та практика раціонального використання традиційних і альтернативних паливно-мастильних матеріалів: Монографія / за заг. ред. проф. С. В. Бойченка. - К.: Центр навчальної літератури, 2017. - Розд. І. - С. 8-13.

6. Sergii Boichenko. Phenomenological concept of chemmotology / Sergii Boichenko // Proceedings of National Aviation University. - 2017. - № 1. - P. 113-119. DOI: 10.18372/2306-1472.70.11431.

7. S. Boichenko, O. Vovk, I. Shkilniuk, K. Lejda. Traditional and alternative jet fuels: problems of quality standardization // Journal of Petroleum \& Environmental Biotechnology. 2013. - Vol. 4. - Iss. 3. DOI: http://dx.doi.org/10.4172/2157-7463.1000146.

8. Яковлева А.В., Бойченко С.В. Потенциал использования биотоплив на основ растительных масел в авиации // Охрана окружающей среды и природопользование. - ОАО «НИИ Атмосфера». - СанктПетербург. - № 2. - 2013. - С. 18-27.

9. Iakovlieva A.V. Overview of innovative technologies for aviation fuels production A.V. Iakovlieva, S.V. Boichenko, O. O. Vovk // Journal of Chemistry and chemical technology. - 2013. - Vol. 7. - № 3. - P. 305312.

10. Біохімічний метод отримання етилового спирту / С. М. Гарасимчук, А. О. Азаренкова, М. С. Бойченко, М. Н. Барановський // Наукоємні технології. - 2014. - Т. 21. - №1. - С. $18-21$.

11. Авиационная химмотология: топлива для авиационных двигателей. Теоретические и инженерные основы применения: учебник / Н. С. Кулик, А. Ф. Аксенов, Л. С. Яновский, С. В. Бойченко. К.: НАУ, 2015. - 560 c.

12. Л.М. Черняк, М.С. Бойченко, М.М. Захарчук, А.В. Яковлєва Світові проблеми та перспективи впровадження альтернативних палив 3 водоростей // Екологічний інтеллект - 2012. VII Міжнародна науково-практична конференція молодих вчених, 24-25 квітня 2012 р.: тези доп. - Дніпропетровськ, 2012. - C. 205-206.

13. Kasturi Dutta, Achlesh Daverey, Jih-Gaw Lin. Evolution retrospective for alternative fuels: First to fourth generation // Renewable Energy. - 2014. - V. 69. - P. 114-122.

14. Sudhakar K., Premalatha M. Theoretical Assessment of Algal Biomass Potential for Carbon Mitigation and Biofuel Production // Iranical Jornal of Energy and Environment. - 2012. - №3. - P. 232-240.

15. Hussain K., Nawaz K., Majeed A. Lin F. Economically Effective Potential of Algae for Biofuel Production // World Applied Sciences Journal. - 2010. №9(11). - P. 1313-1323.

16. Моторні палива: властивості та якість. Підручник / Сергій Бойченко, Андрій Пушак, Петро Топільницький, Казимир Лейда; за заг. ред. проф. С. Бойченка. - К.: НАУ, 2017. - 328 с.

17. Abraham M. Asmare, Berhanu A. Demessie,Ganti S. Murthy. Theoretical Estimation the Potential of Algal Biomass for Biofuel Production and Carbon Sequestration in Ethiopoa // International Journal of Renewable Energy Research. - 2013. - Vol. 3. - №3. - P. 560-570.

18. Теплица Експерт, 2017 - Електронний ресурс [Режим доступу] http://teplicaexp.ru/tag/osveshhenie/

19. Sudhakar K., Rajesh M., Premalatha M. A Mathematical Model to Assess the Potential of Algal BioFuels in India // Energy Sourses. - 2012. Part A, 34. - P. 1114-1120.

20. Giuseppe Torzillo, Benjamin Pushparaj, Jiri Masojidek, Avigad Vonshak. Biological Constraints in Algal Biotechnology // Biotechnology and Bioprocess Engineering. - 2003. - №8. - P. 338-348.

21. Карта солнечной активности в Украине, 2017 - Електронний ресурс [режим доступу] http://www.solar-battery.com.ua/karta-solnechnoy-aktivnosti-v-ukraine/

22. Jacovides C. P., Timvios F. S., Papaioannou G., Asimakopoulos D. N., Theofilou C. M. Ratio of PAR to Broadband Solar Radiation Measured in Cyprus // Agricultural and Forest Meteorology. - 2004. - №121. - P. 135-140.

23. Pooja K. Himabindu V. Mixotrophic Cultivation of Botryococcus Braunii for Biomass and Lipid Yields with Simultaneous CO2 Sequestration // Journal of Engineering Research and Applications. - 2014. - Vol. 4, Issue 10 (Part - 6). - P. 151-156.

24. Chan-Hee Lee, Hyun-Sik Chae, Seung-Hoon Lee, Han Soon Kim. Growth Characteristics and Lipid Content of three Korean Isolates of Botryococcus Braunii (Trebouxiophyceae) // Ecology and Environment. 2015. - №38 (1). - P. 67-74.

25. Asma J. Yusoff F. M., Srikanth R. M. Growth Rate Assessment of High Lipid Producing Microalga Botryococcus braunii in Different Culture Media // Iranian Journal of Fisheries Sciences. - 2015. - №14 (2), - P. 436-445.

26. Khalid A. Al-Hothaly, Aidyn Mouradov, Abdulatif A. Mansur, Brian H. May, Andrew S. Ball, Eric M. Adetutu. The Effect of Media on Biomass and Oil Production in Botryococcus braunii Strains Kossou-4 and Overjuyo-3 // International Journal of Clean Coal and Energy. - 2015. - №4. - P. 11-22.

27. Xu H., Miao X. L., Wu Q. Y. High Quality Biodisel Production from a Microalga Chlorella Protothecoides by Heterotrophic Growth in Ferments // Jurnal of Biotechnology. - 2006. - №126. - P. 499-507. 
28. Delgadillo-Mirquez L., Lopes F., Taidi B., Pareau D. Nitrogen and Phosphate Removal from Wastewater with a Mixed Microalgae and Bacteria Culture // Biotechnology Reports. - 2016. - №11. - P. 18-26.

29. Manea R. G., Ardelean I. I. Nitrogen and Phosphorus Removal from Municipal Wastewater Using Cinsortia of Photosynthetic Microorganisms // Scientific Bulletin. Series F. Biotechnologies. - 2016. - Vol. XX. - P. 286-292.

30. Singh R., Birru R., Sibi G. Nitrogen Removal Efficiencies of Chlorella Vulgaris from Urban Wastewater for Reduced Eutrophication // Journal of Environmental Protection. - 2017. - №8. - P. 1-11.

31. Shamanskyi S., Boichenko S. Development of Environmentally Safe Technological Water Disposal Scheme of Aviation Enterprise / С. Й. Шаманський, С. В. Бойченко // Восточно-европейский журнал передовых технологий. - 2016. - №6/10(84). - С. 49-57.

S. Shamanskyi, Cand. Sc. (Eng.) M. Boichenko, Ph.D. student

L. Pavliukh, Cand. Sc. (Eng.) Assoc. Prof.

National Aviation University MODELING OF MASS AND LIPID PPRODUCTIVITY OF MICROALGAE CULTIVATION IN THE KYIV REGION

In article prospects of the third and fourth generation of biofuels production were analyzed. The algae cultivation with high lipid content in biomass as a raw material for this production is proposed. The influence of illumination intensity of the culture medium on the cultivation productivity, using the energy balance of photosynthesis, is considered. The mathematical model of calculating the cultivation productivity in open capacities depending on the solar radiation intensity is proposed. Based on the average monthly solar radiation levels in the Kyiv city, received by NASA, which are averaged based on 20 years observations by illumination level of the territory of Ukraine, the cultivation productivity during the year for weather conditions in the Kyiv region was estimated using the proposed model. The resulting productivity with productivity which can be achieved in other parts of the world was compared. To increase the economic efficiency of biofuel production, it is proposed to use as a culture medium pre-purified municipal sewage by traditional methods. This will enable to combine the processes of raw materials cultivation for biofuels and the processes of sewage purification from biogenic elements.

Key words: biofuel, cultivation efficiency, lipids, sewage treatment, biogenic elements.

\section{References}

1. Sorokina K. N., Yakovlev V.A, Piligayev A.V, Kukushkin R. G., Peltek S. E., Kolchanov N. A., Parmon V. N. The potential of application of microalgae as a raw material for bioenergetics // Catalyst in industry. - 2012. №2. - P. 63-72.

2. Boichenko S.V. Rational use of hydrocarbon fuels. - K .: NAU, 2001. - 216 p.

3. Introduction to the chemotology of fuels and oils: A manual in two parts / S. Boichenko, V. Spirkin Odessa: "Astroprint", 2009. - Ch. 1. - 236 p.

4. Aksenov A. F., Seregin E. P., Yanovskii L. S., Boichenko S. V. Modern Paradigm and Prospects of Chemmotology Development // Chemistry and Technology of Fuels and Oils. - № 4 (578). - 2013. - P. 13-20.

5. Boichenko Sergii. Chemotology as Applied Science - Integrated Theoretical and Methodological Tool for the Sustainable Provision of Rational Use of Fuels and Lubricants / Alexander Aksenov, Sergii Boichenko, Kazimir Leida / / Problems of chemotology. Theory and practice of rational use of traditional and alternative fuels and lubricants: Monograph / per comp. Ed. prof. S.V Boichenko. - K .: Center for Educational Literature, 2017. Part. I. - P. 8-13.

6. Sergii Boichenko. Phenomenological concept of chemmotology / Sergii Boichenko // Proceedings of National Aviation University. - 2017. - № 1. - P. 113-119. DOI: 10.18372/2306-1472.70.11431.

7. S. Boichenko, O. Vovk, I. Shkilniuk, K. Lejda. Traditional and alternative jet fuels: problems of quality standardization // Journal of Petroleum \& Environmental Biotechnology. 2013. - Vol. 4. - Iss. 3. DOI: http://dx.doi.org/10.4172/2157-7463.1000146.

8. Yakovlieva A.V, Boichenko S.V. The potential of using biofuels on the basis of vegetable oils in aviation // Environmental protection and nature management. - JSC "Atomosphere Research Institute". - St. Petersburg. - No. 2. - 2013. - P. 18-27.

9. Iakovlieva A.V. Overview of innovative technologies for aviation fuels production A.V. Iakovlieva, S.V. Boichenko, O. O. Vovk // Journal of Chemistry and chemical technology. - 2013. - Vol. 7. - № 3. - P. 305312.

10. Biochemical method of obtaining ethyl alcohol / S.M. Garasymchuk, A.O. Azarenkova, M.S. Boichenko, M.N. Baranovsky // Science-based technologies. - 2014 - T. 21. - No. 1. - P. 18-21. 


\section{ISSN 1813-5420 (Print). Енергетика: економіка, технології, екологія. 2017. № 4}

11. Aviation Chemmotology: Fuel for Aviation Engines. Theoretical and engineering fundamentals of application: a textbook / M. S. Kulyk, A. F. Aksenov, L. S. Yanovsky, S. V. Boichenko. - K .: NAU, 2015 - 560 pp.

12. L.M. Chernyak, M.S. Boichenko, M.M. Zakharchuk, A.V. Yakovlieva. World problems and prospects for implementation of alternative fuels from algae // Ecological Intellect - 2012. VII International Scientific and Practical Conference of Young Scientists, April 24-25, 2012: theses of additional. - Dnipropetrovsk, 2012. - P. 205-206.

13. Kasturi Dutta, Achlesh Daverey, Jih-Gaw Lin. Evolution retrospective for alternative fuels: First to fourth generation // Renewable Energy. - 2014. - V. 69. - P. 114-122.

14. Sudhakar K., Premalatha M. Theoretical Assessment of Algal Biomass Potential for Carbon Mitigation and Biofuel Production // Iranical Jornal of Energy and Environment. - 2012. - №3. - P. 232-240.

15. Hussain K., Nawaz K., Majeed A. Lin F. Economically Effective Potential of Algae for Biofuel Production // World Applied Sciences Journal. - 2010. №9(11). - P. 1313-1323.

16. Motor fuels: properties and quality. Textbook / Sergii Boichenko, Andrii Pusach, Peter Topolnytskii, Kazimir Leida; per community Ed. prof. S. Boichenko. - K .: NAU, 2017. - 328 p.

17. Abraham M. Asmare, Berhanu A. Demessie,Ganti S. Murthy. Theoretical Estimation the Potential of Algal Biomass for Biofuel Production and Carbon Sequestration in Ethiopoa // International Journal of Renewable Energy Research. - 2013. - Vol. 3. - №3. - P. 560-570.

18. Hothouse Expert, 2017 - Electronic resource [Access mode] http://teplica-exp.ru/tag/osveshhenie/

19. Sudhakar K., Rajesh M., Premalatha M. A Mathematical Model to Assess the Potential of Algal BioFuels in India // Energy Sourses. - 2012. Part A, 34. - P. 1114-1120.

20. Giuseppe Torzillo, Benjamin Pushparaj, Jiri Masojidek, Avigad Vonshak. Biological Constraints in Algal Biotechnology // Biotechnology and Bioprocess Engineering. - 2003. - №8. - P. 338-348.

21. Карта солнечной активности в Украине, 2017 - Електронний ресурс [режим доступу] http://www.solar-battery.com.ua/karta-solnechnoy-aktivnosti-v-ukraine/

22. Jacovides C. P., Timvios F. S., Papaioannou G., Asimakopoulos D. N., Theofilou C. M. Ratio of PAR to Broadband Solar Radiation Measured in Cyprus // Agricultural and Forest Meteorology. - 2004. - №121. - P. 135-140.

23. Pooja K. Himabindu V. Mixotrophic Cultivation of Botryococcus Braunii for Biomass and Lipid Yields with Simultaneous CO2 Sequestration // Journal of Engineering Research and Applications. - 2014. - Vol. 4, Issue 10 (Part - 6). - P. 151-156.

24. Chan-Hee Lee, Hyun-Sik Chae, Seung-Hoon Lee, Han Soon Kim. Growth Characteristics and Lipid Content of three Korean Isolates of Botryococcus Braunii (Trebouxiophyceae) // Ecology and Environment. 2015. - №38 (1). - P. 67-74.

25. Asma J. Yusoff F. M., Srikanth R. M. Growth Rate Assessment of High Lipid Producing Microalga Botryococcus braunii in Different Culture Media // Iranian Journal of Fisheries Sciences. - 2015. - №14 (2), - P. 436-445.

26. Khalid A. Al-Hothaly, Aidyn Mouradov, Abdulatif A. Mansur, Brian H. May, Andrew S. Ball, Eric M. Adetutu. The Effect of Media on Biomass and Oil Production in Botryococcus braunii Strains Kossou-4 and Overjuyo-3 // International Journal of Clean Coal and Energy. - 2015. - №4. - P. 11-22.

27. Xu H., Miao X. L., Wu Q. Y. High Quality Biodisel Production from a Microalga Chlorella Protothecoides by Heterotrophic Growth in Ferments // Jurnal of Biotechnology. - 2006. - №126. - P. 499-507.

28. Delgadillo-Mirquez L., Lopes F., Taidi B., Pareau D. Nitrogen and Phosphate Removal from Wastewater with a Mixed Microalgae and Bacteria Culture // Biotechnology Reports. - 2016. - №11. - P. 18-26.

29. Manea R. G., Ardelean I. I. Nitrogen and Phosphorus Removal from Municipal Wastewater Using Cinsortia of Photosynthetic Microorganisms // Scientific Bulletin. Series F. Biotechnologies. - 2016. - Vol. XX. - P. 286-292.

30. Singh R., Birru R., Sibi G. Nitrogen Removal Efficiencies of Chlorella Vulgaris from Urban Wastewater for Reduced Eutrophication // Journal of Environmental Protection. - 2017. - №8. - P. 1-11.

31. Shamanskyi S., Boichenko S. Development of Environmentally Safe Technological Water Disposal Scheme of Aviation Enterprise / С. Й. Шаманський, С. В. Бойченко // Восточно-европейский журнал передовых технологий. - 2016. - №6/10(84). - С. 49-57.

Надійшла 05.12.2017

Received 05.12.2017 